\title{
Rozważania nad periodyzacją dziejów polskiej architektury po 1918 roku zainspirowane wystawą „Tożsamość. 100 Lat polskiej architektury"
}

\author{
Hubert Trammer \\ https://orcid.org/0000-0001-8885-4323 \\ huberttrammer@wp.pl,h.trammer@pollub.pl \\ Katedra Architektury Urbanistyki i Planowania Przestrzennego, \\ Wydziat Budownictwa i Architektury, Politechnika Lubelska
}

\begin{abstract}
Streszczenie: Zaproponowana przez twórców wystawy Tożsamość. 100 lat polskiej architektury periodyzacja dziejów polskiej architektury po roku 1918 z podziałem na okresy 1918-1939, 1939-1956, 1956-1970, 1970-1989 i 1989-2018 budząc wątpliwość stanowi punkt wyjścia do refleksji, przeglądu innych periodyzacji dziejów architektury tego czasu oraz przedstawienia własnych propozycji w tym zakresie.
\end{abstract}

Słowa kluczowe: architektura polska, periodyzacja, historia architektury.

\section{Wprowadzenie}

Przypadająca w 2018 roku setna rocznica odzyskania przez Polskę niepodległości stała się inspirację do szeregu podsumowań i wydarzeń z nią związanych. Także w zakresie architektury. Najbardziej doniosłym z tych dotyczących architektury była wystawa Tożsamość. 100 lat polskiej architektury zorganizowana przez Narodowy Instytut Architektury i Urbanistyki, która została zaprezentowana w 2019 roku. Zastosowany na niej podział chronologiczny wzbudził moje wątpliwości i tym samym zainspirował do przyglądnięcia się zagadnieniu periodyzacji polskiej architektury po roku 1918. Dzieje, w tym dzieje architektury, można prezentować w ujęciu chronologicznym lub tematycznym. Osobiście uważam ujęcie tematyczne za właściwsze. Jednakże ze względu na to, iż ujęcie chronologiczne jest szeroko rozpowszechnione uważam, iż warto jest poddawać refleksji to w jaki sposób chronologia jest tworzona i jakie nadawane są jej ramy.

\section{Wystawa Tożsamość. 100 lat polskiej architektury i jej struktura}

Wystawa Tożsamość. 100 lat polskiej architektury została podzielona na pięć części. Każda została pokazana w innym mieście. Podział wystawy na części wiązał się z podziałem na wybrane pięć tematów wystawy, oraz na przedziały czasowe, na które podzielony został okres 1918-2018. Twórcy wystawy przyjęli i zasadniczo zrealizowali bardzo ciekawe założenie prezentacji każdego z pięciu tematów oraz pięciu okresów na przykładzie miasta, w którym odbywała się dana część wystawy. W efekcie każda z części wystawy wiązała miasto, w którym była prezentowana, temat i przedział czasowy. W Krakowie zaprezentowano okres 1918-1939 i temat Sztuka, w Warszawie - okres 1939-1956 i temat Władza, w Lublinie - okres 1956-1970 i temat Społeczeństwo, w Poznaniu - okres 1970-1989 i temat Transfer, w Katowicach - okres 1989-2018 i temat Przemiana. Nie wszystkie 
części wystawy w pełni trzymały się wyznaczonych ram. Na wystawie w Krakowie została zaprezentowana, jako jedna z pokazywanych realizacji Wystawa Architektury i Wnętrz w Otoczeniu Ogrodowym, która odbyła się w Krakowie w roku 1912. Na wystawie w Warszawie pokazany został projekt dzielnicy Marszałka Józefa Piłsudskiego opracowany w latach 1936-1939, a więc tylko zahaczający o graniczny rok. Na wystawie w Poznaniu zostały pokazane gościńce wybudowane w różnych miejscach w Wielkopolsce, dwa przykłady z Murowanej Gośliny osiedle Zielone Wzgórza i niezrealizowany projekt Domu Społecznego, a także projekty zrealizowane za granicami Polski. To ostatnie wynikało wprost z tematu poznańskiej części wystawy, jakim był Transfer. W przypadku Katowic w zakres wystawy weszła szeroka prezentacja przykładów z innych miast Górnego Śląska ${ }^{1}$. Osiedle nad Jamną w Mikołowie autorstwa Stanisława Niemczyka wykracza też poza ramy czasowe wystawy - pochodzi z lat 1986-1989. Przy tym pisząc o zawartości poszczególnych części wystawy mam na myśli ich zasadnicze części. Bowiem na każdej z pięciu wystaw umieszczone zostały także plansze prezentujące odniesienie do całego okresu 1918-2018 i wybranych przykładów z całego terenu Polski².

\section{Ocena struktury wystawy Tożsamość. 100 lat polskiej architektury}

Niewątpliwą zaletą przyjętej przez twórców wystawy koncepcji ${ }^{3}$ jest rozszerzenie jej zasięgu w sposób dosłowny - poprzez zbliżenie do miejsc zamieszkania, pracy, czy nauki większej liczby osób niż gdyby odbyła się ona w jednym mieście. Oczywiście poznanie całości wystawy wymagało przebycia więcej kilometrów. Jednak klasyczna wystawa pokazująca wszystko w jednym miejscu oznacza, iż jedni mają blisko a inni daleko do całej wystawy. Podział na części sprawił też, że wystawa stawała się pretekstem do odwiedzenie różnych miejsc w Polsce. Oczywiście pytanie ile osób zdecydowało się na takie podróże.

Zawężenie przykładów z określonych tematów czy okresów do tych zlokalizowanych w miejscu wystawy także jest interesującym rozwiązaniem. Każda przekrojowa wystawa musi bowiem opierać się na wyborze wąskiego fragmentu prezentowanej rzeczywistości. Decyzja podjęta przez twórców wystawy Tożsamość. 100 lat polskiej architektury ostentacyjnie unaocznia, iż wystawa prezentuje przykłady będące wycinkiem rzeczywistości a nie jest jej całościową prezentacją. Można mieć zastrzeżenie do tego iż skupienie się na dużych i wielkich miastach będących miejscami wystawy a nie na regionach powoduje zmarginalizowanie mniejszych ośrodków i terenów wiejskich. Poniekąd wynagradza to zrealizowany równolegle z wystawą Tożsamość. 100 lat polskiej architektury w dziewięciu mniejszych ośrodkach cykl działań pod nazwą Infrastruktura niepodległości: architektura powiatowych projektów modernizacyjnych ${ }^{4}, \mathrm{w}$ dalszej fazie promowanych i zaprezentowanych pod nazwą Dwudziestolecie w Twoim powiecie ${ }^{5}$.

Wybór pięciu spośród ponad dziewięciuset miast w oczywisty sposób jest wyborem swego rodzaju próbki. Można mieć zastrzeżenie do nadreprezentacji południowo-wschodniej Polski, a także braku jakiegokolwiek miasta z terenu ziem odzyskanych. Można także zastanawiać się czy nie warto byłoby zrezygnować z Warszawy i Krakowa na rzecz ośrodków, którym dotychczas poświęcono mniej wystaw i publikacji, a przez to dać im szansę zaistnienia w szerszej świadomości, którą dostały Lublin i Poznań, czy Katowice. Jednakże w przypadku tego doboru można mieć nadzieję iż nie ma ryzyka iż dobór tych właśnie pięciu miast stworzy kanon.

Także dobór pięciu tematów jest skupieniem się na pięciu zagadnieniach i także jest indywidualną cechą wystawy. Co więcej uznałbym go za trafny. Także w tym przypadku nie ma chyba ryzyka utrwalenia się tego doboru jako rodzaju kanonu.

1 Zwracam uwagę, iż nie popełniam tu błędu typowego dla osób nieznających specyfiki aglomeracji Śląsko-Dąbrowskiej. Na wystawie nie było przykładów z Zagłębia Dąbrowskiego, były za to z Bytomia, Gliwic, Mikołowa, Rudy Śląskiej i Rybnika.

2 Opis wystawy i jej zawartości w oparciu o zapoznanie się na miejscu z wszystkimi pięcioma częściami wystawy oraz o towarzyszącą wystawie publikację książkową pod tym samym co wystawa tytułem Tożsamość. 100 lat polskiej architektury (Stelmach (red.), $\backslash$ Andrzejewska-Batko (red.) 2019).

3 Koncepcja wystawy, wraz z doborem tematów oraz podziałem na przedziały czasowe została opracowana przez dyrektora Narodowego Instytutu Architektury i Urbanistyki Bolesława Stelmacha po dyskusjach z zaproszonych przez niego do nich architektami. Jednym z punktów odniesienia była seria artykułów opublikowanych w 2018 roku w dwumiesięczniku ARCH z okazji setnej rocznicy odzyskania przez Polskę niepodległości- informacje uzyskana od Bolesława Stelmacha w rozmowie telefonicznej. O periodyzacji wyłaniającej się z publikacji w ARCHu piszę w dalszej części niniejszego artykułu. Koordynatorem całości wystawy był Kacper Kępiński, zaś poszczególne części wystawy miały osobnych kuratorów(Stelmach (red.), \Andrzejewska-Batko (red.) 2019, s.372).

4 http://niaiu.pl/infrastruktura-niepodleglosci/

5 http://niaiu.pl/2019/12/wystawa-dwudziestolecie-w-twoim-powiecie/ 


\section{Ocena periodyzacji zaproponowanej przez twórców wystawy Tożsamość. 100 lat polskiej architektury}

W odróżnieniu od doborów dokonanych w kwestii lokalizacji i tematów, dobór okresów na które podzielono wystawę jest doborem całościowym, w pełni pokrywającym zakres czasowy całej wystawy i może się on utrwalić jako rodzaj kanonu. Stąd też wydaję mi się iż warto uczynić go przedmiotem rozważań, oceny, oraz punktem wyjścia do dyskusji.

Wynikający z setnej rocznicy odzyskania niepodległości stuletni okres jaki objęła wystawa został podzielony na pięć części: 1918-1939, 1939-1956, 1956-1970, 1970-1989 i 1989-2018. Warto zwrócić uwagę na długość tych okresów. Mają one odpowiednio po: 21, 17, 14, 19 i 29 lat. Czyli najdłuższy z tych okresów jest ponad dwukrotnie dłuższy niż najkrótszy. Okazuje się to tym bardziej interesujące, gdy uświadomimy sobie, iż na 100 lat, jakie upłynęły od odzyskania niepodległości w 1918 roku do setnej rocznicy tego wydarzenia, składa się równo po 50 lat kiedy Polska była niepodległa (1918-1939 i 1989-2018) oraz 50 lat kiedy niepodległa nie była. Oczywiście niektórzy mogą argumentować, iż nigdy pełnej niepodległości nie ma i uważać stwierdzenie o braku niepodległości w latach 1944-1989 rokiem za niezasadne i zaznaczać iż istnienie państwa polskiego będącego podmiotem prawa międzynarodowego, którego władze na miejscu zarządzają jego terytorium jest jednoznaczne z niepodległością, bądź też twierdzić iż obecna pewna zależność od Stanów Zjednoczonych Ameryki Północnej i Unii Europejskiej też może być uznana za ograniczenie niepodległości. Wejście Polski do NATO - Paktu Północnoatlantyckiego, w którymi dominują Stany Zjednoczonymi Ameryki Północnej, oraz większa niż przypadku wielu innych członków NATO gotowość Polski do wspierania inicjatyw Stanów Zjednoczonych Ameryki Północnej, oraz wejście Polski w skład Unii Europejskiej są wynikiem decyzji demokratycznie wybranych władz. A to ostatnie zostało zatwierdzone znaczącą większością głosów w referendum ${ }^{6}$. Może ktoś na to podnieść argument, że Polska w latach 1926-1939 nie była państwem demokratycznym. O ile dyskusje na temat tego czy Polska Rzeczpospolita Ludowa była państwem niepodległym się toczą, o tyle pogląd iż nie była jest w Polsce poglądem dominującym, a wiele z osób go niepodzielających zgodzi się z tym, iż była mniej niepodległa niż w latach 1918-1939 i po roku 1989. Wracając do będącej tematem niniejszego artykułu periodyzacji trzeba zauważyć że niepodległe lub bardziej niepodległe pięćdziesięciolecie zostało na wystawie zaprezentowane w dwóch częściach liczących po 21 i 29 lat (1918-1939 i 1989-2018), zaś pięćdziesięciolecie kiedy, zależnie do punktu widzenia, niepodległości nie było lub było jej mniej na trzy okresy po 17, 14 i 19 lat (1939-1956, 1956-1970 i 1970-1989). Jeszcze drastyczniej sprawa będzie wyglądała jeśli zwrócimy uwagę iż okres między odzyskaniem niepodległości w 1918, a jego setną rocznicą, składa się z dwóch okresów niepodległości (1918-1939 i 1989-2018) i przypadającej między nimi przerwy (1939-1989). Wówczas okaże się że dwa osobne okresy niepodległości potraktowane zostały całościowo, zaś jeden okres przerwy w niepodległości rozbity na trzy części.

Czy zatem aktywność w okresie (zależnie od punktu widzenia) braku niepodległości, lub dużo bardziej niż zwykle ograniczonej niepodległości jest dużo bardziej złożona i skomplikowana i należy się jej przyglądać bardziej szczegółowo? A może po prostu podział na okresy wynika z tego że oddzielają je momenty przełomowe, momenty zmian, sprawiające że sytuacja przed i po tych momentach wygląda zupełnie inaczej. Nie ulega wątpliwości, że w dziejach Polski lata 1939, 1956, 1970 i 1989 były momentami przełomowymi. Podążając za przedstawioną wyżej logiką za najbardziej przełomowe należy uznać lata 1939 i 1989. Przy tym na zdecydowanie pierwsze miejsce wysuwa się rok, 1939 kiedy to w następstwie wybuchu II Wojny Światowej do Polska została podzielona między Niemcy i Związek Radziecki, a struktury polskiego państwa przeniosły się do "podziemia" i na emigrację. Rok 1956 był przełomowy ze względu na koniec zbrodniczej epoki stalinizmu wprowadzenie szeregu wolności. Rok 1970 to związana z dramatycznymi wydarzeniami (krwawo zakończone protesty robotnicze) zmiana na szczytach komunistycznej władzy powszechnie postrzegana jako odejście od ascetycznej polityki pod rządami Władysława Gomułki na rzecz bardziej konsumpcjonistycznej i korzystającej z zagranicznych kredyty epoki pod rządami Edwarda Gierka. Czy nie było innych momentów przełomowych? Z pewnością przełomowy był rok 1945 kiedy skończyła się II Wojna Światowa.

6 W przeprowadzonym w dniach 7 i 8 czerwca 2003 roku referendum ogólnokrajowym w sprawie wyrażenia zgody na ratyfikację Traktatu dotyczącego przystąpienia Rzeczypospolitej Polskiej do Unii Europejskiej ważna głosy oddało 58.85\% spośród uprawnionych do głosowania, Na tak zagłosowało $77,44 \%$ uprawnionych do głosowania. źródło: https://referendum2003.pkw.gov.pl/sww/kraj/indexA.html 
Odnosząc się do niepodległości i jej odzyskiwania nie można pominąć roku 1980 kiedy powstał ruch Solidarność, który w 1989 roku, choć działał w zmienionym kształcie, to był siłą mającą decydujące znaczenie dla tego, że w 1989 roku to właśnie Polska była awangardą wychodzenia z zależności od Związku Radzieckiego. To właśnie w Polsce powstał pierwszy w krajach zależnych od Związku Radzieckiego rząd z premierem nienależącym do partii komunistycznej. Protesty robotnicze roku 1988, które do tego doprowadziły odbywały się właśnie pod znakiem Solidarności ${ }^{7}$. Zatem bez zdarzeń roku 1980, to co zdarzyło się w roku 1989 mogłoby wydarzyć się później. Przełom roku 1980 można cofnąć do roku 1976 (protesty w Radomiu i Ursusie i powstanie po wywołanych nimi represjach Komitetu Obrony Robotników, oraz rozwój podziemnego rynku wydawniczego, początki kryzysu gospodarczego), lub roku 1978 (mający duży wpływ na rozwój sytuacji w Polsce wybór Karola Wojtyły na papieża Jana Pawła II, powstanie Wolnych Związków Zawodowych, a także ostatni rok przed załamaniem gospodarczym, które zapoczątkowała zima stulecia). W roku 1978 oddano do użytku najwięcej mieszkań w historii Polski. W okresie po 1989 roku z pewnością przełomowym rokiem w historii Polski był rok 2004 - rok wejścia do Unii Europejskiej, co zapoczątkowało szereg bardzo istotnych zmian. Przełomowy był także rok 1999 (wejście Polski do NATO oraz wejście w życie reformy administracyjnej znacząco zwiększającej uprawnienia samorządów, a przez to decentralizującej władzę w Polsce).

W okresie 1918-1939 przełomowy był rok 1926 (przewrót majowy obalający demokrację), rok 1924 (reforma walutowa Władysław Grabskiego, która zakończyła okres hiperinflacji, a jednocześnie ze względu na oparcie waluty na parytecie złota stworzyła poważny hamulec rozwojowy) rok 1920 (zwycięstwo w wojnie z Rosją Radziecką), rok 1929 (początek wielkiego kryzysu).

Ponieważ wystawa dotyczy architektury warto spojrzeć na przyjęte progi pomiędzy przedziałami czasowymi nie tylko z punktu widzenia generalnych przełomów dziejowych, ale także przełomów w architekturze. Z przyjętych na wystawie dat progowych niewątpliwie najbardziej przełomowy był rok 1939 kiedy to w wyniku wybuchu wojny rzeczywistość budowlana a co za tym idzie także architektoniczna uległa ogromnemu przeorientowaniu. Część architektów zginęła, część została zamordowana. Ci którzy zachowali lub ponownie uzyskali możliwość pracy w zawodzie, mogli działać jedynie w biurach kierowanych przez Niemców. W wyniku walk, a także planowanych działań okupanta wiele obiektów było niszczonych. O ile powyżej napisałem o braku niepodległości w okresie 1939-1989, o tyle, zależnie od obszaru okres 1939-1945 lub 1939-1944 to jedyny okres w odniesieniu do którego zasadne jest wygłoszenie tezy, iż znacząca część powstającej wówczas na terenie Polski architektury nie była architekturą polską.

Na drugim miejscu pod względem, przełomowości z przyjętych przez twórców wystawy dat progowych należy postawić rok 1956. Nastąpiło wówczas przypieczętowanie podczas Ogólnopolskiej Narady Architektów odwrotu od socrealizmu w architekturze ${ }^{8}$ i początek okresu triumfu w niej modernizmu.

Trzecie miejsce dałbym rokowi 1989 . Związany z nim przełom związany ze znacznym ograniczeniem roli państwa w budownictwie doprowadził choćby do zmiany pozycji technologii wielkiej płyty z dominującej w budownictwie mieszkaniowym wielorodzinnym do niemal wcale nie stosowanej. Spadła rola planowania i urbanistyki.

Rok 1970, przyjęty przez twórców wystawy za jedną z dat granicznych, oznaczał zmianę w kierunkach i ilości inwestycji, czy choćby odejście od generalnego kursu na oszczędności, ale w skali stulecia polskiej architektury w moim przekonaniu należałoby go uznać za moment korekty a nie przełomu.

Wśród przełomowych dla architektury datami, które nie stały się progami między poszczególnymi częściami wystawy na czoło wysuwa się ponownie rok, 1945 kiedy zakończyła się II Wojna Światowa i rozpoczęła odbudowa. Równie ważnym przełomem jak kończący socrealizm rok 1956 był rozpoczynający go rok, 1949 kiedy został on zadekretowany podczas Krajowej Partyjnej Narady Architektów ${ }^{9}$ Można by nawet uznać, iż był on przełomem ważniejszym, gdyż z proklamowaniem socrealizmu nie nastąpiło wyłącznie zepchnięcie na margines form modernistycznych w architekturze, ale szerzej odejście od pluralizmu w architekturze. Socrealizm w architekturze nie oznaczał zastąpienia dotychczas stosowanych form nowymi, a jedynie zawężenie spektrum stosowanych form. Z kolei odrzucenie socrealizmu w roku 1956 nie było powrotem do sytuacji sprzed 
roku 1949, lecz zastąpieniem jednego wiodącego kierunku drugim. Okres ograniczenia pluralizmu ${ }^{10}$ trwał nadal. Jego końca można upatrywać miedzy rokiem 1978 a 1980. I tamten moment należałoby uznać za kolejny ważny przełom. W moim przekonaniu dla architektury zdecydowanie ważniejszy niż przyjęty przez twórców wystawy rok 1970. Po roku 1980 zostały wprowadzone działania stopniowo wprowadzające możliwość w miarę niezależnego uprawiania zawodu architekta - możliwość zakładania spółdzielni w ramach których działały autorskie pracownie, a potem wręcz tworzenie prywatnych pracowni. W roku 1981 uchylony został obowiązujący przedtem normatyw urbanistyczny ${ }^{11}$. Tak więc powszechnie wiązany z rokiem 1989 spadek znaczenia planowania zaczął się już wcześniej.

Istotnym przełomem, pytanie czy nie równie ważnym co rok 1989, wydaje się dla architektury moment wejście do Unii Europejskiej. Na skutek mechanizmów dofinansowania z funduszy Unii Europejskiej nastąpiło przeorientowanie myślenia o inwestycjach z czysto podporządkowanego wolnemu rynkowi na ukierunkowane na możliwości korzystania z funduszy unijnych. Przykładem jest kwestia wpisywanego w obiekty publiczne towarzyszącego programu komercyjnego. Przed wejściem do Unii Europejskiej upatrywano w nim sposobu na pokrycie kosztów funkcjonowania, czy wręcz wybudowania obiektu. Po wejściu do Unii Europejskiej okazał się być balastem utrudniającym uzyskanie dofinansowania ze środków Unii Europejskiej. Generalnie środowisko architektów w latach 1989-2004 ukierunkowane było na wolny rynek ${ }^{12}$. Wejście do Unii Europejskiej w istotny sposób to zmieniło. Zbiegło się z nim oddanie do użytku Muzeum Powstania Warszawskiego w Warszawie ${ }^{13}$, które okazało się ogromnym sukcesem i z pewnością było czynnikiem wzmagającym boom na duże obiekty kultury, których budowanie ułatwiały zasady uzyskiwany funduszy Unii Europejskiej. Takie obiekty w latach 1980-2004 powstawały w ilościach dużo mniejszych nie tylko niż po roku 2004, ale także niż przed rokiem 1980, a wiele z tych które powstawały było budowami rozpoczętymi w poprzednich latach i w nielicznych tylko przypadkach kończonymi w tym okresie.

Wreszcie rok 2004 jest cezurą także ze względu na rozwój publikacji i wystaw dotyczących architektury. Lata 1989-2004 były w tym zakresie zdecydowanie latami chudymi. Obecnie mamy do czynienia z ogromnym boomem.

Podsumowując periodyzacja przyjęta na potrzeby wystawy Tożsamość. 100 lat polskiej architektury wydaje mi się w części dyskusyjna. W szczególności wątpliwości budzi wydzielenie osobnego czternastoletniego okresu 1956-70, w sytuacji kiedy jednocześnie jako jeden okres został potraktowany cały dwudziestodziewięcioletni czas po roku 1989.

\section{Przegląd przykładów periodyzacji architektury polskiej po roku 1918 zastosowanych w wybranych publikacjach}

Dwumiesięcznik ARCH wydawany przez Stowarzyszenie Architektów Polskich w 2018 roku w pięciu kolejnych numerach (od numeru 2(46) do numeru 6 (50) w dziale Temat numeru opublikował cykl artykułów prezentujących architekturę polską po 1918 roku. Podział na pięć numerów, a więc na tyle samo części ile miała wystawa Tożsamość. 100 lat polskiej architektury daje bardzo dobre porównanie. Artykuły wchodzące w skład cyklu każdorazowo zostały poprzedzone rozkładówką z ilustracją i tytułem Temat numeru. 100 lat w polskiej architekturze uzupełnionym określonym w latach przedziałem czasowym, którego dotyczyły. Kolejne publikacje dotyczyły okresów: 1918-1939 - artykuł Anny Dybczyńskiej-Bułyszko Architektura dwudziestolecia międzywojennego ${ }^{14}$, 1939-1945-1956 - opracowany przez Agnieszkę Bulandę oparty na cytatach tekst Okupacja ${ }^{15}$ i artykuł Anny

10 Piszę tu o ograniczeniu, gdyż pełnego odrzucenie pluralizmu nie było. Obiekty architektury modernistycznej powstawały także w okresie socrealizmu, zaś obiekty o formach tradycyjnych także w okresie 1956-1978/1980. Jednak choćby ze względu na zawartość publikacji dotyczących architektury uzasadnione jest stwierdzenie o tym że lata 1949-1978/1980 są okresem generalnego braku pluralizmu oraz obowiązywanie stusznego kierunku - innego przed 1956 i innego po tymże roku.

11 Cymer 2018a, s. 365

12 Piątek 2018, s. 18-19

13 Otwarcie Muzeum miało miejsce 1 sierpnia 2004 roku, a więc trzy miesiące po wejściu do Unii Europejskiej.

14 Dybczyńska-Bułyszko 2018, s. 20-34

15 Bulanda 2018 , s. $16-25$ 
Cymer W obliczu nowego porząku. Architektura w Polsce 1945-1956 ${ }^{16}, 1945-1989$ artykuł Marty Leśniakowskiej Pót wieku, ${ }_{1}^{17}$ 1989-2004 - artykuł Grzegorza Piątka Czas komercji. Architektura polskiej transformacji 1989-2004 ${ }^{18}$, oraz 2004-2018 - artykuł Michała Owadowicza Kilka uwag na marginesie dyskusji o architekturze ostatnich kilkunastu lat, toczonej z okazji setnej rocznicy zjednoczenia ziem polskich i odzyskania petnej podmiotowości politycznej przez naród polski ${ }^{19}$. Jak widać dwa z powyższych przedziałów czasowych nakładają się na siebie. Z treści obejmującego okres 1945-1989 artykułu Marty Leśniakowskiej wynika, iż prądy i kierunki się przenikają i nawet socrealizm o ściśle zadekretowanych początku i końcu nie jest ściśle wydzielonym okre$\mathrm{sem}^{20}$. Z doboru przedstawionych okresów rysują się następujące progi czasowe: 1939,1945,1956,1989 i 2004. Nie ma więc, zastosowanej przez twórców wystawy Tożsamość. 100 lat polskiej architektury kwestionowanej przeze mnie cezury roku 1970, dochodzi zaś cezura roku 2004 na którą także ja wskazałem. Cezura roku 1945 jest zaznaczona, ale ze względu na ujęcie okresu 1939-1945 w tym samym numerze co okresu 1945-1956, można uznać za potraktowanie prezentacji tego szczególnego wojennego okresu jako połączonej z prezentacją czasu następującego po nim. Nota bene na wystawie Tożsamość. 100 lat polskiej architektury czas wojny został niemal pominięty. Periodyzacja przyjęta w serii okolicznościowych publikacji miesięcznika ARCH jest tu o tyle istotnym punktem odniesienia, iż Bolesław Stelmach przy formowaniu podziału wystawy Tożsamość. 100 lat polskiej architektury na części brał ją za punkt jeden z punktów wyjścia ${ }^{21}$. Tym bardziej uwypukla to wydzielenie przez niego bardzo krótkiego okresu 1956-1970 kosztem potraktowania zbiorczo długiego okresu 1989-2018.

W miesięczniku Architektura-murator setna rocznica odzyskania niepodległości została uczczona zbiorem prezentacji zatytułowanym 100 budynków na stulecie. 100 lat zostało podzielonych równo na dziesięć dziesięcioleci. Redakcja poprosiła o wskazanie po dziesięć realizacji dla każdego z dziesięcioleci inną osobę będącą architektem, a jednocześnie badaczem architektury, jej krytykiem i nauczycielem akademickim. Oprócz budynków część z zaproszonych osób wskazała zespoły urbanistyczne, przestrzenie publiczne, czy obiekty sportowe wymykające się definicji budynku ${ }^{22}$. W tym przypadku cezury wynikają z przyjęcia podziału prezentowanych dziejów na równe okresy. Tak więc podział na przedziały czasowe jest z jednej strony obiektywny, zaś z drugiej strony nieoparty na żadnych zdarzeniach/momentach progowych, ani też okresach o wyróżniającej je charakterystyce.

Andrzej K. Olszewski w książce Nowa forma w architekturze polskiej 1900-1925. Teoria i praktyka zarysował podziat chronologiczny architektury polskiej 1 połowy XX wieku według trzech zasadniczych etapów rozwoju modernizmu w następujący sposób:

OKRES I 1900-1925 Pierwsza faza rozwoju modernizmu. Pierwsza generacja modernistów ("starzy”) podzielony na trzy podokresy -

1. PODOKRES 1900-1905/1908. SECESJA, PRZEJŚCIE OD HISTRORYZMU DO MODERNIZMU [,]

2. PODOKRES 1905/1908-1914 ROZWÓJ MODERNIZMU. PIERWSZA GENERACJA (...) [,]

3. PODOKRES 1918-1925 NAWRÓT DO FORM HISTORYCZNYCH (...) [;]

OKRES II 1925-1934 Druga faza modernizmu, druga generacja modernistów („młodzi"). Funkcjonalizm, styl międzynarodowy. Dalszy etap rozwoju „szkoły warszawskiej" (...)

OKRES III 1934-1949 Półmodernizm lat trzydziestych, "wolny funkcjonalizm”, "nowy regionalizm", trzecia generacja modernistów, ostatni etap "szkoły warszawskiej" podzielony na trzy podokresy

\footnotetext{
16 Cymer 2018b, s. 26-40

17 Leśniakowska 2018, s.16-40

18 Piątek 2018, s. $18-34$

19 Owadowicz 2018, s. 16-32

20 Leśniakowska 2018, s. 16-17

21 Informacja uzyskana od Bolesława Stelmacha w rozmowie telefonicznej.

22100 budynków na stulecie 2018, s. 24-45
} 


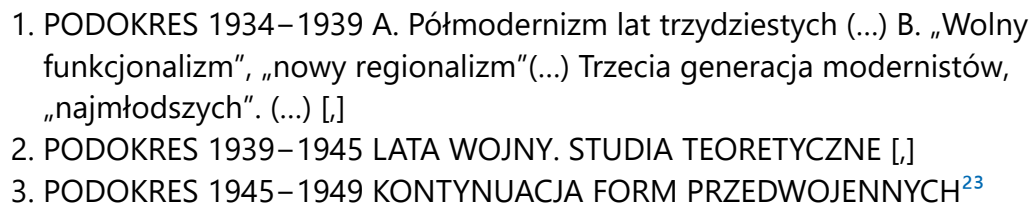

Ten podział oparty na stosowanych formach architektonicznych, wbrew temu co mogłoby się na wydawać na pierwszy rzut oka nie ograniczony do architektury modernistycznej jest szczególnie interesujący ze względu na to, iż Andrzej K. Olszewski uznał cezury lat 1918 i 1938 uważane obecnie za fundamentalne, za mniej istotne od cezur lat 1925 i 1934. Pierwsze półwiecze XX wieku (1900-1949) zostało podzielone na trzy okresy oddzielone od siebie cezurami lat 1925 i 1934, które wyrastają na główne cezury, oraz na podokresy, za pomocą dodatkowych cezur lat 1905/1908, 1914, 1918, 1939 i 1945. Przy tym lata obu wojen światowych są szczególnie potraktowane. Czas między latami 1914 i 1918 nie jest objęty żadnym podokresem, zaś lata 1939-1945 są określone jako czas studiów teoretycznych.

W 1984 roku Andrzej Gliński, Zyta Kusztra i Stefan Müller opublikowali w dwumiesięczniku Architektura cykl artykułów zatytułowany Architektura polska 1944-1984. Poszczególne artykuły (nazwane przez autorów rozdziałami) odpowiadają przedziałom czasowym na jakie autorzy podzielili cały okres. Dodatkowo dodali do nich tytuły z których tylko Realizm socjalistyczny opiera się na powszechnie przyjętym dziś terminie związanym z opisywanym okresem. Pozostałe natomiast są, przynajmniej z dzisiejszego punktu widzenia, ciekawym nowym spojrzeniem na temat. Określona przez Glińskiego, Kusztrę i Müllera periodyzacja przedstawia się następująco: Lata 1944-1949 [:] Walka z historyzmem ${ }^{24}$, Lata 1949-1956 [:] Realizm socjalistyczny ${ }^{25}$, Lata 1956-1965 [:] Poszukiwania ${ }^{26}$, Lata 1965-1975 [:] Skrajny technologizm ${ }^{27}$, Lata 1975-1983 [:] Ekspresjonizm eklektyczny ${ }^{28}$. Z mojego punktu widzenia szczególnie ciekawy przy podziale czterdziestoletniego okresu na pięć części jest brak cezury roku 1970 i umieszczenie go po środku okresu określonego jako Skrajny technologizm.

Interesujące jest pojawienie się cezur lat 1965 i 1975, a także cezury 1944 zamiast 1945. Oczywiście powodem możemy być zbieżność daty publikacji z czterdziestą rocznicą proklamowania Polskiej Rzeczypospolitej Ludowej. Ale można uznać to za wydarzenie na tyle istotne, iż stosowanie cezury roku 1944 ma w odniesieniu do Polski uzasadnienie. Można dopatrywać się w tym podziale podobnego jak przyjęty w 2018 roku przez redakcję miesięcznika Architektura-murator ${ }^{29}$ podziału na równe części. Jednakże wczytanie się w treść opracowania Glińskiego, Kusztry i Müllera prowadzi do stwierdzenia że jest inaczej. Rok 1965 jest wskazany ze względu na zmianę funkcjonowania zawodu architekta. Prezentacja okresu 1965-1975 określonego jako Skrajny technologizm rozpoczyna się od słów Likwidacja Komitetu Urbanistyki i Architektury, podporządkowanie biur projektowych resortowi budownictwa oraz narzucenie dyktatu wykonawstwa biurom projektowym, które w większości weszły w skład struktur zjednoczeń budownictwa praktycznie ograniczyło do minimum możliwości projektowania. W wyniku tego systemy organizacji biur projektowych preferowaty rozwiazania typowe i powtarzalne (...) ${ }^{30}$. Znaczenie cezury 1965 roku podkreśla poświęcenie przez Glińskiego Kusztrę i Müllera okresowi 1956-1965 określonemu jako Poszukiwania dwukrotnie więcej miejsca niż pozostałym. Poświęcony mu rozdział opublikowali w dwóch częściach/artykułach w kolejnych dwóch numerach. Opis zajmuje tyle samo. Dodatkowe miejsce zostało przeznaczone na obszerniejszą niż w innych częściach prezentację realizacji oraz cytatów ze źródeł z epoki. To poświęcenie więcej uwagi okresowi 1956-1965 można uznać za zbieżność z uprzywilejowaniem okresu 1956-1970 przez Bolesława Stelmacha. Być może zarówno on jak i Andrzej Gliński, Zyta Kusztra i Stefan Müller uznali to co się działo w architekturze polskiej w latach po roku 1956 za najbardziej wartościowe w całych okresach, które prezentowali.

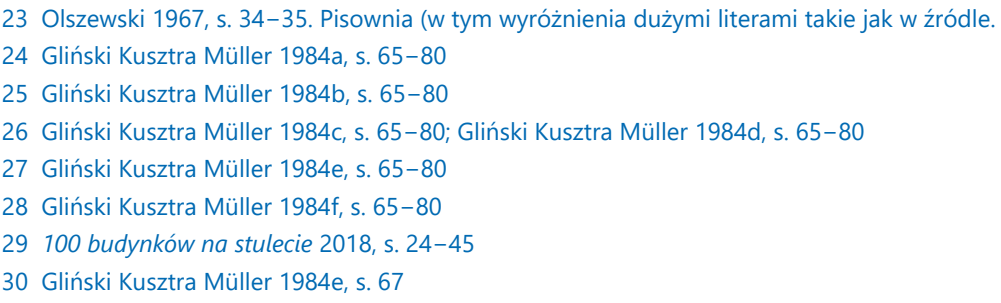


W 2018 roku Instytut Architektury wydał dwutomową publikację Teksty modernizmu. Antologia polskiej teorii i krytyki architektury 1918-1981 na którą składają się Tom 1: Źródła i Tom 2: Eseje $e^{31}$. Tytuł nie oddaje w pełni zawartość, bowiem teksty lub wybrane przez redaktorki fragmenty tekstów, które zawiera Tom 1: Źródła pochodzą z lat 1916-1984. Zostały one pogrupowane w czterech ułożonych chronologicznie częściach. Część modernizm międzywojenny zawiera teksty opublikowane pierwotnie w latach 1916-1939, część odbudowa i socrealizm - w latach 1945-1956, część socmodernizm - z lat 1956-1978, zaś część krytyka modernizmu - z lat $1978-1984^{32}$. Te okresy w moim przekonaniu można uznać nie tylko za trafne w odniesieniu do modernizmu, ale także za przekonujące okresy w historii polskiej architektury jedynie z poprawką na to, iż pierwszy z nich lepiej byłoby wówczas zamiast modernizm międzywojenny nazwać okres międzywojenny. Z podziałów zarysowanych w owej publikacji oraz z jej tytułu wyłaniają się cezury lat 1916, 1918, 1939, 1945, 1956, 1978, 1981 i 1984. Przy tym pierwsza i ostatnia mogą wynikać bardziej z chęci pokazania tego co działo się przed i po. Takie spojrzenie uważam za bardzo wartościowe. Pokazuje że początek i koniec nie są momentami, lecz procesami. Jedna z redaktorek publikacji Dorota Jędruch stwierdza: (...) Wytyczony przez nas horyzont czasowy - od końca I wojny światowej do powolnego upadku układu wpływów sowieckich i zimnowojennej rywalizacji - wpisuje się [w] teorię „krótkiego XX wieku" Erica Hobsbawma ${ }^{33}$.(...)

W 2018 roku ukazała się książka Anny Cymer Architektura w Polsce 1945-198934. Zakres tematyczny zahacza o okres od 1940 roku poruszony w rozdziale Mimo wojny- przygotowania ${ }^{35}$. Podział treści książki na części nie jest ściśle chronologiczny. Ostatnia, siódma, część zatytułowana Architektura sakralna obejmuje cały zakres chronologiczny książki ${ }^{36}$. Z kolei cześć pierwsza Odbudowa dotyczy okresu od roku 1940 do $1959^{37}$ zahaczając tym samym o zakres czasowy trzech z pozostałych pięciu części książki. Te pięć części zostało sformułowanych chronologicznie. Jednakże daty i chronologia nie są w centrum uwagi autorki i owe części w swoich zakresach czasowych się częściowo zazębiają. Co notabene unaocznia umowność wyznaczanych datami okresów, czy wręcz epok. Część druga Tuż po wojnie. Między modernizmem a socrealizmem ${ }^{38}$ obejmuje okres od 1945 do 1956 roku. Część trzecia Socrealizm ${ }^{39}$ obejmuje zasadniczo okres 1949-1956, ale w przypadku Nowej Huty i Nowych Tychów sięga do obiektów powstałych później. Część czwarta Powrót do nowoczesności ${ }^{40}$ dotyczy architektury z lat 1956-1975. Część piąta Lata 70. Architektura w kryzysie $e^{41}$ obejmuje okres od roku 1970. Cezurę końcową trudno ustalić gdyż autorka prezentuje wiele realizacji których budowy trwały bardzo długo. Niektóre zakończyły się dopiero w latach dziewięćdziesiątych. Z pewnym uproszczeniem można jednak przyjąć iż owa część sięga do roku 1982. Szósta część Lata 80. Nie tylko postmodernizm ${ }^{42}$ zasadniczo rozpoczyna się od niedatowanego ściśle końca lat siedemdziesiątych, ale pierwszym przywołanym wspomnianym wydarzeniem wskazującym na odwrót od modernizmu jest opisanie przez Kazimierza Wejcherta, jak wskazuje Anna Cymer wbrew przyjętym standardom i normatywom w wydanej w 1974 roku książce Elementy kompozycji urbanistycznej zalet urbanistyki sprzed modernizmu ${ }^{43}$. Najpóźniejsze daty to lata 1997 i 1998 kiedy ukończono ostatnie z prezentowanych w niej obiektów.

Zatem wśród nieostro określonych przez Annę Cymer przedziałów czasowych można dopatrywać się cezur 1940, 1949, 1956-1959, 1970, 1975- przełom lat siedemdziesiątych i osiemdziesiątych-początek lat osiemdziesiątych, 1980. Przy tym na najbardziej istotne wyrastają określone cezura roku 1956 oraz cezura która można lokować między rokiem 1975 a początkiem lat osiemdziesiątych.

\footnotetext{
31 Jędruch (red.) Karpińska (red.) Leśniak-Rychlak (red.) 2018a, Jędruch (red.) Karpińska (red.) Leśniak-Rychlak (red.) 2018b

32 Jędruch (red.) Karpińska (red.) Leśniak-Rychlak (red.) 2018a

33 Jędruch 2018, s.27-28. Cytowany fragment kończy się przypisem bibliograficznym: E. Hobsbawm, Wiek skrajności, Spojrzenie na krótkie XX stulecie, Warszawa, Krytyka Polityczna, 2018

34 Cymer 2018a

35 Cymer 2018a, s. 7-11.

36 Cymer 2018a, s. 395-461

37 Cymer 2018a, s. 7-37.

38 Cymer 2018a, s. 39-63

39 Cymer 2018a, s. 65-119

40 Cymer 2018a, s. 121-266

41 Cymer 2018a, s. 269-345

42 Cymer 2018a, s. 347-392

43 Cymer 2018a, s. 365
} 


\section{Rozważania wyjściowe do propozycji periodyzacji architektury polskiej po roku 1918}

Dokonana powyżej ocena periodyzacji zaproponowanej przez twórców wystawy Tożsamość. 100 lat polskiej architektury, oraz przegląd wybranych innych periodyzacji skłaniają mnie do stwierdzenia że przyjmując zachowanie zasady podziału stulecia na pięć części cezurę roku 1970 należałoby zastąpić cezurą umiejscowioną później - podkreślająca doniosłość odrzucenia modernizmu.

Andrzej Gliński, Zyta Kusztra i Stefan Müller w 1984 roku w artykule Architektura polska 1944-1984, rozdziat V, Lata 1975-1983 Ekspresjonizm eklektyczny doniosłość zanegowania modernizmu w latach osiemdziesiątych XX wieku porównali do odrzucenia w 1956 roku socrealizmu ${ }^{44}$. Dziś takie spojrzenie nie jest rozpowszechnione, ale w mojej opinii jest ono słuszne. I to pomimo tego, iż od wielu lat polscy architekci chętniej identyfikują się z modernizmem niż z postmodernizmem.

W pełni podzielam opinię wyrażoną przez Annę Cymer w podsumowaniu rozdziału Lata 80. Nie tylko postmodernizm jej książki Architektura w Polsce 1945-1989 i uważam ją za wartą przywołania w całości.

Dekada lat 80. jest niezwyktym momentem $w$ dziejach XX wiecznej polskiej architektury. Choć była hamowana przez katastrofalny kryzys, zaowocowała wieloma znaczącymi realizacjami będacymi nie tylko zapisem etapu przejściowego między gospodarka centralnie sterowana a kapitalizmem, lecz także znakiem wielkich przemian $w$ filozofii, estetyce $i$ kulturze. Odejście od modernizmu, otwarcie na nowe formy, pomysty i rozwiazania przestrzenne po dekadach dominacji jednej koncepcji urbanistyczno-architektonicznej- to gigantyczna zmiana, dzięki której architektura i urbanistyka mogły zacząć przybierać nowe lub zapomniane formy. Owocem tej przemiany staty się obiekty dziś nierzadko krytykowane, uznawane za kiczowate lub marnej jakości. Jeśli jednak spojrzy się na nie pod kątem ówczesnej sytuacji gospodarczej i politycznej, a jednocześnie w szerszym kontekście prąów istniejących wcześniej w architekturze krajów Zachodu, okaże się, że ta niedoceniana, zapomniana, uważana za bezproduktywna epoka fascynująco odbija możliwości ówczesnej kultury, stanowiąc kluczowe ogniwo w rozwoju wspótczesnej architektury ${ }^{45}$.

Kolejne istotne zagadnienie warte wzięcia pod uwagę to podkreślana w wielu publikacjach ciągłość ideowa między architekturą polską przed i po II wojnie światowej. Być może więc dla jej podkreślenia przy periodyzacji dziejów architektury polskiej należałoby zrezygnować z oczywistych cezur dziejowych lat 1939 i/lub 1945, tak jak notabene uczynił Andrzej K. Olszewski dzieląc pierwszą połowę XX wieku na trzy podstawowe okresy 1900-1925, 1925-1934 i 1934-194946.

Idąc dalej tym tropem można się zastanowić czy także cezura roku 1989 jest cezurą oczywistą. Z punktu widzenia dążenia do spełnienia polskiego marzenia z dziedziny polityki historycznej, aby powszechnie funkcjonującym w świecie symbolem upadku komunizmu przestał być upadek muru berlińskiego, a jego miejsce zajęły wcześniejsze wydarzenia w Polsce, najbardziej doniosłym wydarzeniem mogącym zawalczyć o rangę symbolu jest powstanie w 1980 roku Niezależnego Samorządnego Związku Zawodowego Solidarność. Zbiega się to czasowo z okresem nasilenia się krytyki modernizmu. Okres lat osiemdziesiątych XX wieku to także okres przemian w architekturze, a w szczególności w sposobie uprawiania zawodu. Stopniowo powstające wówczas prywatne pracownie architektoniczne odegrały istotną rolę w latach dziewięćdziesiątych. Idee i opracowania studialne rozwijane w latach osiemdziesiątych, mogłyby stanowić znakomite przygotowanie dla sytuacji zmienionych realiów. Przykładem może być plon warsztatów Konfrontacje warszawskie'86. Od osiedla do śródmieścia ${ }^{47}$ dotyczących przekształcenia położonego w centrum Warszawy modernistycznego Osiedla Za Żelazną Bramą w przestrzeń o charakterze śródmiejskim. Rozwiązania zaproponowane w powstałych podczas warsztatów projektach zakładały istotne dogęszczenia zabudowy. Niestety opracowania te w większości pozostały niewykorzystane. Osiedla Za Żelazną Bramą zostało dogęszczone, ale w sposób nieskoordynowany i oprócz nadania miejskiego charakteru ulicy Grzybowskiej i stworzeniu zachodniej pierzei Alei Jana Pawła II, szansa na nadanie temu terenowi miejskiego charakteru została zaprzepaszczona.

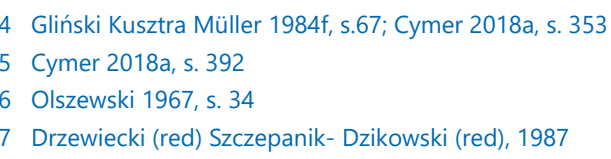


Wartą zastanowienia się kwestią jest także to czy przy wyznaczaniu kolejnych okresów należy, co mogłoby wydawać się oczywiste i co zwykle się czyni, dążyć do wydzielenia od siebie okresów wyraźnie się różniących. A może właśnie podział powinien być tak ustawiony, aby obrazował zachodzące procesy przemian?

\section{Propozycje periodyzacji architektury polskiej po roku 1918}

Kształtując propozycje dotyczące periodyzacji będę odnosił się do przedziału czasowego 1918-2018 stanowiącego ramy czasowe wystawy Tożsamość. 100 lat polskiej architektury, która jest punktem wyjścia do niniejszych rozważań. Jednakże z uwagi na to, iż czas wciąż płynie mam też na uwadze kwestię przydatności zaproponowanych cezur na przyszłość.

Jako pierwszą chciałbym rozważyć, na pierwszy rzut oka mechaniczną i przypadkową periodyzacją opartą na podziale stulecia na równe okresy 1918-1938, 1938-1958, 1958-1978, 1978-1998 i 1998-2018. Paradoksalnie okazuje się być to bardzo ciekawa periodyzacja. Okres 1938-1958 obejmuje panowanie nad Polską okres najbardziej okrutnych totalitaryzmów - hitleryzmu i komunizmu w wydaniu stalinowskim, wraz z okresami tuż przed i tuż po, a także okresem tuż po II Wojnie Światowej kiedy mimo stalinowskiego terroru w sferze ścisłej polityki, w wielu dziedzinach życia pozostawał pewien zakres swobód, wielu też żywiły nadzieję iż stalinowski komunizm nie jest jeszcze przesądzony. Lata 1938-1939 to okres kiedy zdawano sobie w Polsce sprawę z zagrożenia ze strony Niemiec i Związku Radzieckiego, a także próbowano mu zapobiec. Czego przejawem była budowa Centralnego Okręgu Przemysłowego mająca ścisłe przełożenie na architekturę. To także niestety okres haniebnych tendencji w środowisku architektów. W 1938 czerwcu 1938 roku do statutu Stowarzyszenia Architektów Rzeczypospolitej SARP dodano zapis, iż Osoby narodowości żydowskiej nie moga być zwyczajnymi i nadzwyczajnymi członkami SARPu, osoby zaś pochodzenia żydowskiego moga być zarejestrowane na członków na podstawie pozytywnego wniosku Komisji Kwalifikacyjnej. W efekcie w 1939 roku członkostwa w SARPie zostali pozbawieni należący do stowarzyszenia Żydzi ${ }^{48}$.

Cezura roku 1958 oznacza umieszczenie w jednym przedziale czasowym z socrealizmem okresu wychodzenia z niego, którego symptomy widać już od roku 1954, a także okres odwilży politycznej, która około 1958 roku dobiegała końca. W architekturze cezura ta nie jest tak ostra jak w innych dziedzinach życia, ale też można ją zauważyć. Okres 1958-1978 objąłby lata ścisłej dominacji modernizmu. Rok 1978 pasuje dobrze na cezurę. To rok wyboru arcybiskupa krakowskiego Karola Wojtyły na papieża Jana Pawła II, rok wybudowania największej w historii Polski liczby mieszkań, co czyni go rokiem największego triumfu modernistycznej z ducha technologii wielkiej płyty. Jednocześnie wraz z końcem tego roku rozpoczęła się zima stulecia obnażająca niedostatki państwa. Wreszcie rok 1978 to rok publikacji przez Czesława Bieleckiego przełomowego tekstu Ciągłość w architekturze będącego daleko posuniętą krytyką modernizmu ${ }^{49}$. Z kolei rok 1998 to rok zatwierdzenia tak zwanych czterech wielkich reform rządu Jerzego Buzka. Reforma administracyjna w dużej mierze zdecentralizowała zarządzanie państwem. Istotną część kompetencji władz centralnym oddano władzom szczebla wojewódzkiego. To na szczeblu województwa podejmowana jest duża część decyzji odnośnie dofinansowania inwestycji ze środków unijnych. Jednocześnie w samych województwach władze i dyrekcje ich szczebla są skoncentrowane w ich stolicach ${ }^{50}$. Regulacja zawodu architekta została przekazana nowo utworzonym kilka lat później Okręgowym Izbom Architektów, których zasięg jest tożsamy z obszarem województw, a ich siedziby znajdują się w miastach wojewódzkich. Koncentracja dotyczy to w dużym stopniu także prowadzonych przez władze wojewódzkie instytucji nie będących władzami - na przykład instytucji kultury. W efekcie podział administracyjny ma swoje przełożenie także na to jakie miasta mają więcej impulsów rozwojowych, w tym też tego w jakich miastach powstały prestiżowe obiekty architektoniczne. W zakresie architektury rok 1998 to moment kiedy duża, a jeśli nie duża to na pewno wpływowa, część polskiego środowiska architektów zdążyła już odrzucić postmodernizm.

5014 z 16 województw ma po jednej stolicy, a 2 województw (kujawsko-pomorskie i lubuskie) mają po dwie stolice - instytucje szczebla wojewódzkiego rozdzielone tam między dwa miasta. Poza tym są pojedyncze przypadki lokalizacji instytucji szczebla wojewódzkiego w innych miastach niż stolica województwa. 
Podział na okresy 1918-1938, 1938-1958, 1958-1978, 1978-1998 i 1998-2018, dotyczy ściśle stulecia 1918-2018. Tak więc w przypadku tworzenia przeglądów dziejów obejmujących dłuższe okresy wymagałby zredefiniowania.

Kolejna moja propozycja periodyzacji opiera się na poszukiwaniu istotnych cezur. Z przekonaniem mogę wskazać tu cezury lat 1956, 1980 i 2004. Największy problem mam z cezurą najwcześniejszą. Kuszące jest przyjęcie za Andrzejem K. Olszewskim ${ }^{51}$ cezury przed rokiem 1939 co pozwala na uwypuklenie łączności między tym co przed i po II wojnie światowej. Rok 1934 budzi wątpliwości ze względu na to że przedział 1934-1956 obejmowałby i lata przedwojenne i socrealizm. Aczkolwiek zarówno koniec lat trzydziestych jak i czas socrealizmu to czas wielu istotnych architektonicznie instytucji państwowych. Być może zasadne byłoby przesunięcie cezury z roku 1934 na rok 1935. Zmarł wtedy Józef Piłsudski - postać kluczowa dla międzywojennej Polski. Stało się to impulsem do wybudowania i planowania szeregu obiektów jego imienia, w tym monumentalnego zespołu urbanistycznego dla Warszawy. W tak przyjętym układzie na stulecie 1918-2018 składałyby się okresy 1918-1935, 1935-1956, 1956-1980, 1980-2004 oraz 2004-2018. Tak ustawiona periodyzacja poprzez ustawienie jako najkrótszych okresów pierwszego (17 lat) i ostatniego (14 lat) i dłuższych okresów pośrednich (21 lat, 24 lata i 24 lata) buduje swoiste ramy podkreślające początek i koniec stulecia. Dodatkowo jest to periodyzacja rozwojowa. Przyjęte cezury mogą być przydatne jeszcze przez kolejne lata na potrzeby kolejnych publikacji czy wystaw prezentujących architekturę polską po roku 1918. Bowiem okres rozwoju zdeterminowanego przez realia Polski w Unii Europejskiej wciąż trwa. W efekcie okres po roku 2004 będzie stopniowo zbliżał się swoim czasem trwania do poprzednich okresów. Podkreślenie dat 1956, 1980 i 2004 daje tej periodyzacji dużą siłę przekazu. Jest to bardzo korzystne z punktu widzenia polskiej polityki historycznej. Ma także odzwierciedlenie w historii architektury. Rok 1956 to rok wielkich nadziei, rok oficjalnego potępienia zbrodni stalinizmu. Rok 1980 to rok związany z powstaniem ruchu Solidarność, który dał jeszcze większą nadzieję i przyniósł wówczas w Polsce bardzo duże uznanie w świecie. Uzyskujemy więc okres 1956-1980 jako okres od nadziei do nadziei. W architekturze jest to okres od oficjalnie ogłoszonego podczas Ogólnopolskiej Narady Architektów odwrotu od socrealizmu w architekturze ${ }^{52}$ będącego początkiem triumfu modernizmu, do momentu jego znaczącej krytyki. Kolejny przedział czasowy 1980-2004 to okres rozpoczęty zrywem wolnościowym i zakończony wejściem do Unii Europejskiej będącym ukoronowaniem marzeń Polaków o jednoznacznym określeniu przynależności do kręgu Europy Zachodniej. Okres 1980-2004 to także okres transformacji Polski i polskiej architektury. Po roku 2004 trwają one nadal, ale już w zupełnie innych warunkach. Najmniej przekonywająca z przyjętych w tym układzie cezur to rok 1935. Można więc zastanawiać się czy nie zastąpić go rokiem 1939. Wydłuża to okres pierwszy i skraca okres drugi. Zaciera też związki między architekturą przed rokiem 1939, a architekturą po roku 1945. Ten ostatni rok, mimo nadziei z jakimi wiązał się koniec wojny z dzisiejszego punktu widzenia jest mniej nośną cezurą niż rok 1939. Lepiej wiązać okres II wojny światowej z okresem po niej niż z całym dwudziestoleciem międzywojennym, trwającym de facto 21 lat.

\section{Zakończenie}

Zaproponowane przeze mnie dwie propozycje periodyzacyjne, a także dokonany przegląd różnych innych ujęć periodyzacyjnych nie wyczerpują tematu. Mam nadzieję że niniejszy artykuł stanie się początkiem dyskusji. Mam też nadzieję iż stanie się on użyteczny przy planowaniu przyszłych wystaw i opracowań dotyczących dziejów polskiej architektury po roku 1918, w których częścią zagadnienia będzie prezentacja ich w ujęciu chronologicznym.

\section{Piśmiennictwo}

[1] 100 budynków na stulecie, 2018, [w:] Architektura-murator 11 (290).

[2] Bielecki C.,1978, Ciagłość w architekturze, Architektura, 3-4. 
[3] Barucki T., 2000, Przełomowa narada architektów [w:] Fragmenty stuletniej historii 1899-1999. Relacje. Wspomnienia. Refleksje, Oddział Warszawski SARP, Warszawa.

[4] Bulanda A., 2018, Okupacja, [w:] ARCH, 3(47)

[5] Cymer A., 2018a, Architektura w Polsce 1945-1989, Centrum Architektury. Narodowy Instytut Architektury i Urbanistyki, Warszawa.

[6] Cymer A., 2018b, W obliczu nowego porządku. Architektura w Polsce 1945-1956, [w:] ARCH, 4 (48).

[7] Dybczyńska-Bułyszko A., 2018, Architektura dwudziestolecia międzywojennego, [w:] ARCH, 2 (46).

[8] Gliński A. Kusztra Z. Müller S., 1984a, Architektura polska 1944-1984 rozdziat I, Lata 1944-1949 Walka z historyzmem, Architektura, 1 (417).

[9] Gliński A., Kusztra Z. Müller S., 1984b, Architektura polska 1944-1984, rozdziat II, Lata 1949-1956 Realizm socjalistyczny, Architektura, 2 (418).

[10] Gliński A. Kusztra Z. Müller S., 1984c, Architektura polska 1944-1984 rozdziat III - część l, Lata 1956-1965 Poszukiwania, Architektura, 3 (419).

[11] Gliński A. Kusztra Z. Müller S., 1984d, Architektura polska 1944-1984 rozdział III - część II, Lata 1956-1965 Poszukiwania, Architektura, 4 (420).

[12] Gliński A. Kusztra Z. Müller S., 1984e, Architektura polska 1944-1984 rozdziat IV, Lata 1965-1975 Skrajny technologizm, Architektura, 5 (421).

[13] Gliński A. Kusztra Z. Müller S., 1984f, Architektura polska 1944-1984, rozdział V, Lata 1975-1983 Ekspresjonizm eklektyczny, Architektura, 6 (422).

[14] Jędruch D., 2018, Przyjemność tekstu <-> piekło wyboru [w:] Jędruch D. (red.) Karpińska M. (red.) Leśniak-Rychlak D. (red.), 2018a, Teksty modernizmu. Antologia polskiej teorii i krytyki architektury 1918-1981. Tom 1: Źródła, Instytut Architektury, Kraków.

[15] Jędruch D. (red.) Karpińska M. (red.) Leśniak-RychlakD. (red.), 2018a, Teksty modernizmu. Antologia polskiej teorii i krytyki architektury 1918-1981. Tom 1: Źródła, Instytut Architektury, Kraków.

[16] Jędruch (red.) Karpińska (red.) Leśniak-RychlakD. (red.), 2018b, Teksty modernizmu. Antologia polskiej teorii i krytyki architektury 1918-1981. Tom2: Eseje, Instytut Architektury, Kraków.

[17] Drzewiecki H. (red) Szczepanik-Dzikowski J. (red), 1987 Konfrontacje Warszawskie'86. Od osiedla do śródmieścia. Przeksztatcanie zachodniego obszaru Osi Saskiej, Stowarzyszenie Architektów Polskich, Warszawa.

[18] Stelmach B. (red.), Andrzejewska-Batko K. (red.), 2019, Tożsamość. 100 lat polskiej architektury, Narodowy Instytut Architektury i Urbanistyki, Warszawa.

[19] Olszewski A. K., 1967, Nowa forma w architekturze polskiej 1900-1925. Teoria i praktyka, Zakład Narodowy im. Ossolińskich Wydawnictwo Polskiej Akademii Nauk, Wrocław, Warszawa, Kraków.

[20] Ost. D. (przekład Jankowska H.), 2007, Klęska Solidarności. Gniew i polityka w postkomunistycznej Europie, Warszawskie Wydawnictwo Literackie MUZA, Warszawa.

[21] Owadowicz M., 2018, Kilka uwag na marginesie dyskusji o architekturze ostatnich kilkunastu lat, toczonej z okazji setnej rocznicy zjednoczenia ziem polskich i odzyskania petnej podmiotowości politycznej przez naród polski, [w:] ARCH, 6 (50).

[22] Piątek G., 2018, Czas komercji. Architektura polskiej transformacji 1989-2004, [w:] ARCH, 5 (49).

[23] Piotrowski R., 2000, Lata trzydzieste w Stowarzyszeniu Architektów Polskich [w:] Fragmenty stuletniej historii 1899-1999. Relacje. Wspomnienia. Refleksje, Oddział Warszawski SARP, Warszawa. 


\section{Consideration on the periodization of history of polish architecture after 1918 inspired by the exhibition "Tożsamość. 100 Lat polskiej architektury" (Identity. 100 Years of polish architecture)}

Abstract: Periodization of the history of Polish architecture after 1918, proposed by the authors of the exhibition /dentity. 100 years of Polish architecture, divides this time into periods 1918-1939, 1939-1956, 1956-1970, 1970-1989 and $1989-2018$. It raised doubts and became a starting point for reflection and for the review of others periodization of the history of architecture of that time and also a presentation of own proposals in this regard.

Keywords: Polish architecture, periodization, history of architecture. 